\title{
銅めっを法の高温領域での適応性*
}

\author{
加 藤

\section{Adaptability of Copper Electro-Plating Method \\ at High Temperatures}

章**

by

\author{
Akira KATO \\ (Chubu Institute of Technology, Kasugai)
}

The author has found that the recrystallization temperature of copper plating rises considerably when a very small quantity of gelatine is added to the plating solution. In this investigation, the copper electro-plating method has been tried at high temperatures by using the plating solution with $4 \mathrm{mg} / 1$ gelatine. The result shows that this method can be applied for stress analysis up to about $250^{\circ} \mathrm{C}$.

(Received July 24, 1978)

キー・ワード : 応力測定, 銅めっき法. 高温

\section{1 緒言}

銅めっきを用いた従来の測定法がそのまを適用でき るのは $80^{\circ} \mathrm{Cが}$ 限界とされている。 これは, 電着銅の再 結晶温度は100〜 $130{ }^{\circ} \mathrm{C}$ ( 1 時間) であるため, 高温で は成長粒子が発生するより前にめっき層に再結晶が起 るので, 成長粒子の発生状態を観測することが不可能 になるからである.

最近, 銅めっきの代りに, 再結晶温度が比較的高い ニッケルめっきを用いて $200^{\circ} \mathrm{C}$ 位までの温度領域で応 力測定に応用した例が報告されている. しかし、ニッ ケルめっきは銅めっきに比較して取扱いがやっかいで あるばかりでなく, 電解研摩が難しいことなどがその 難点である.

銅めっきは取扱いが非常に容易であり，すでにめっ き箔などる開発されていて，作動中の機械部品などに 発生する応力の測定にも利用されている．したがって，
この方法がそのまま高温にまで適用できるよらになれ ば,ささらに実用性の高いものになるとい光る。著者は 最近, 銅めっき液に微量のゼラチンを添加するとめっ き層の再結晶温度が著しく上昇することを発見したの で, 本研究では, ゼラチンを添加しためっき液を用い て実験を行い，銅めっき法が高温領域においても適用 できるか否かを検討してみた。

\section{2 ゼラチン添加量と再結晶温度の関係}

本研究で採用しためっき液の組成出よびめっき条件 は Table I に示したと抢りであるが，これは従来の 銅めっき法で採用されているものと全く同一である.

成長粒子あるいは再結晶を観測する際には, まずり ン酸液を用いてめっき面を電解研摩したのち, グラー ド液 $\left(\mathrm{FeCl}_{3} \cdot 6 \mathrm{H}_{2} \mathrm{O} 10 \mathrm{~g}, \mathrm{HCl} 50 \mathrm{cc}\right.$, 蒸留水 $120 \mathrm{cc}$ ) でエッチングするようにした。

基礎のアルカリめっき層は成長粘子の発生に影響を

Table I. Conditions for deposition.

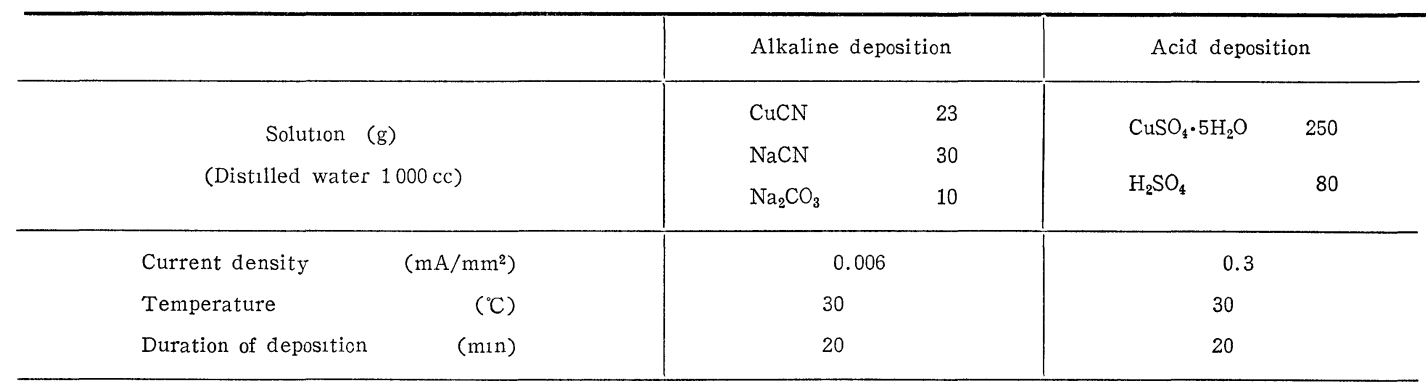

* 原稿受理 昭和53年 7 月 24 日

** 正 会 員 中部工業大学 春日井市松本町 


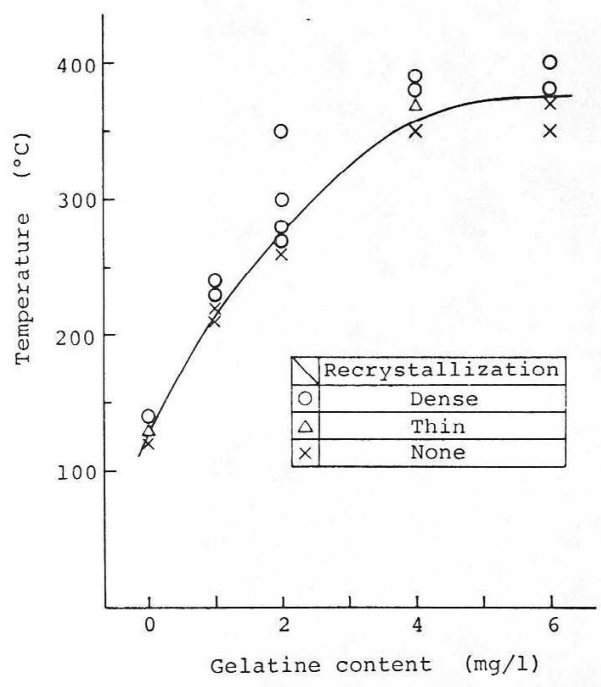

Fig. 1. Relation between recrystallization temperature and gelatine content in the plating solution.

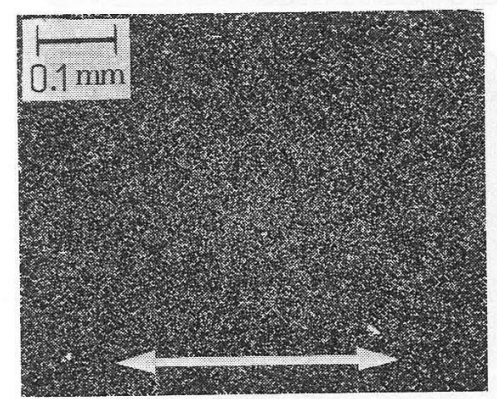

(a) $\sigma=17 \mathrm{~kg} / \mathrm{mm}^{2}$

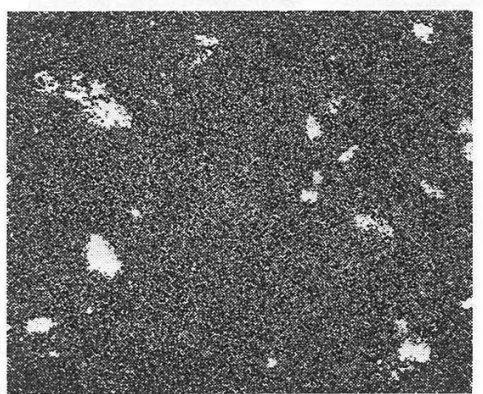

(c) $\sigma=19 \mathrm{~kg} / \mathrm{mm}^{2}$

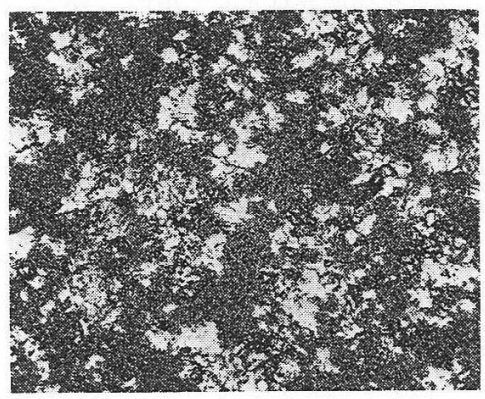

(e) $\sigma=21 \mathrm{~kg} / \mathrm{mm}^{2}$

及ぼさないことがすでに明らかにされているので，本 研究では酸めっき液のみにゼラチンを添加して実験を 行った.

まず，ゼラチンの添加量と再結晶温度の関係を調べ てみた。ここでは，加熱時間を1時間にとり，めっき 層に再結晶粒子が発生し始める限界の温度を求めた。

Fig. 1 に示すように，ビラチンの添加量が增せば再結 晶温度は急激に上昇し，ゼラチンを $3 \mathrm{mg} / 1$ 程度添加 すれば再結晶温度は $300{ }^{\circ}$ 位になることがわかる。

しかし，加熱時間が長くなれば再結晶温度は低くな るし，また繰返し荷重をかければ再結晶を起しやすく なる、したがって，応力測定に実際に利用できる試験 温度は, ここで求めた再結晶温度よりる少し低くなる はずである。もし， $300^{\circ} \mathrm{C}$ 程度の温度でこの方法を応 力測定に利用しょうと思えば， ゼラチンの添加量を $4 \mathrm{mg} / 1$ 以上にしなければならない。乙かし，実験の 結果によれば，それ以上のゼラチンを添加しても再結 晶温度はあまり高くならない。

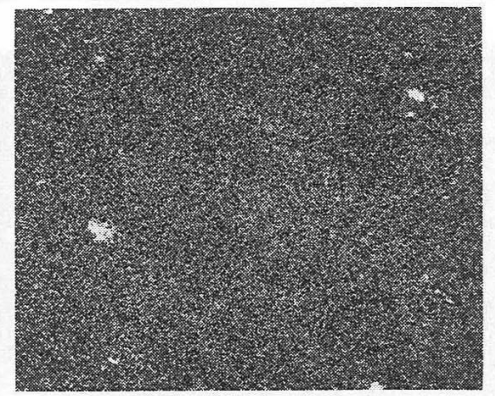

(b) $\sigma=18 \mathrm{~kg} / \mathrm{mm}^{2}$

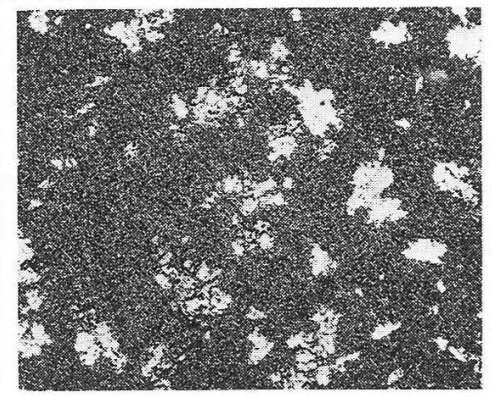

(d) $\sigma=20 \mathrm{~kg} / \mathrm{mm}^{2}$

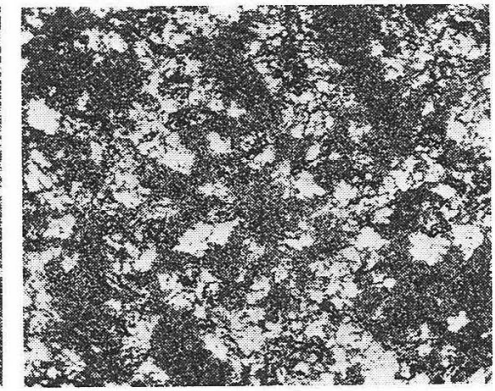

(f) $\sigma=22 \mathrm{~kg} / \mathrm{mm}^{2}$

Fig. 2. Occurrence of grown grains. Arrow indicates line of shaft axis. $\left(150^{\circ} \mathrm{C}, N=1 \times 10^{7}\right)$ 


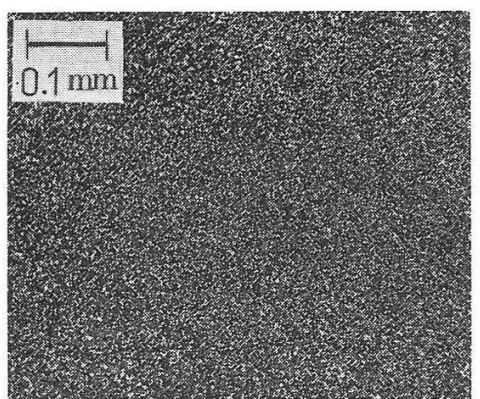

(a) $\sigma=12 \mathrm{~kg} / \mathrm{mm}^{2}$

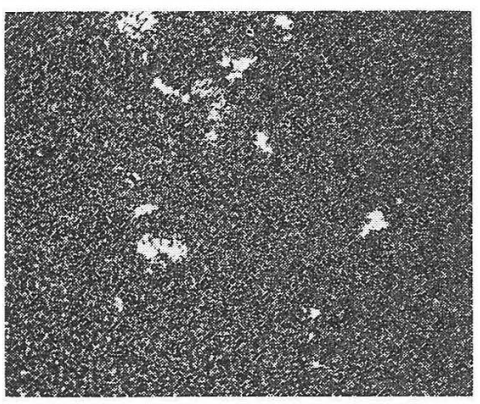

(c) $\sigma=14 \mathrm{~kg} / \mathrm{mm}^{2}$

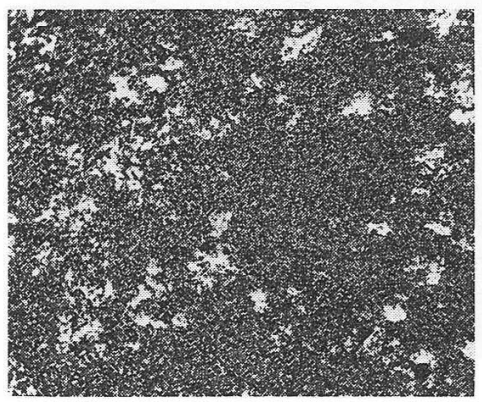

(e) $\sigma=16 \mathrm{~kg} / \mathrm{mm}^{2}$

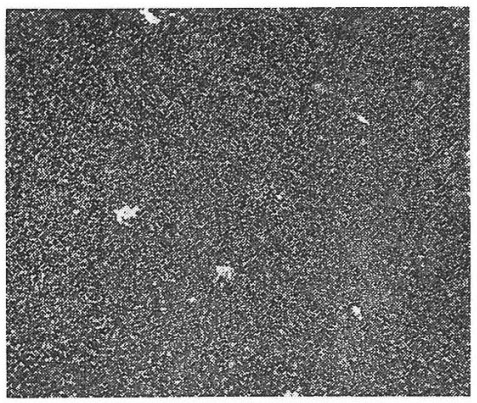

(b) $\sigma=13 \mathrm{~kg} / \mathrm{mm}^{2}$

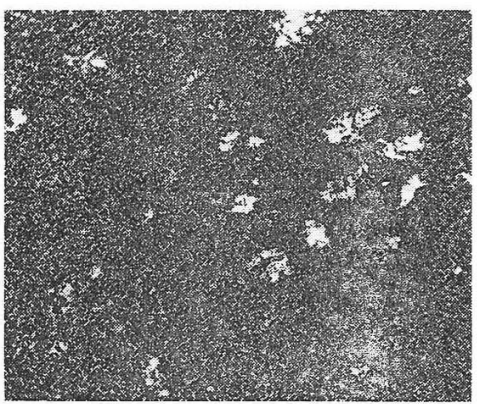

(d) $\sigma=15 \mathrm{~kg} / \mathrm{mm}^{2}$

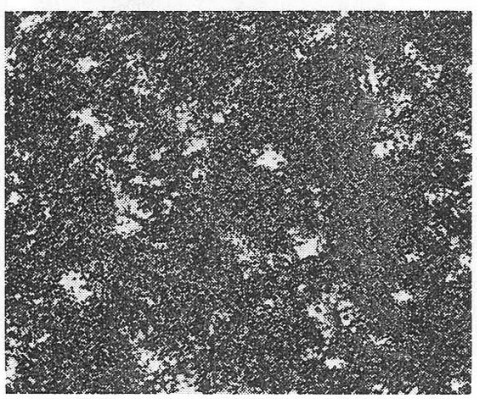

(f) $\sigma=17 \mathrm{~kg} / \mathrm{mm}^{2}$

Fig. 3. Occurrence of grown grains. $\left(200^{\circ} \mathrm{C}, N=1 \times 10^{7}\right)$

以上の実験結果から, 本研究では $4 \mathrm{mg} / 1$ ゼラチン 添加のめっき液を用いることにした。このめっき液を 用いてめっきした試験片に高温に书いて繰返し荷重を 加えたところ，めっき層には成長粒子が発生すること が確認された。しかし，成長粒子の大きさは従来の室 温の場合よりもかなり小さいので, 明確な成長粒子を 得るためには応力絽返し数を多くしなければならない。 しかしながら，成長粒子があまり大きくなれば，微小 部分に和ける成長粒子の発生状態を钼測することなど は困難になるから，成長粒子が小さいことは局部的な 応力を測定するのに適してているい方る。委た同一応 力状態に西る 4 点に括ける成長粒子の発生状態を 1 枚 のフィルムに重权写しにして成長粒子の発生密度を平 均化する四重写しの方法を用いる場合などにも，成長 粒子が小さければ，各点における成長精子が互いに重 なり合らことも少くなり，有利であるといえよう。

応力之成長粒子の発生密度の関係を示す写真の一例
をFig. 2 および3に示した. Fig.2，3 はとれぞれ試 験温度 $150^{\circ} \mathrm{C}$ および $200^{\circ} \mathrm{C}$ の場合で, いずれも応力繰 返し数 $N=1 \times 10^{7}$ の回転曲げ試験を行って得たもの である. 各写真に対応する応力はそれぞれ 5 〜 8\%程 度異っているに過ぎないが，成長粒子の発生状態には はっきりした差が認められる。したがって,これらの 写真を標準写真として用い，実際に湘定しょらとする 試験片に対して同一温度, 繰返し数の下に打娍長 粒子の発生状態を示す写真を求め, これを上記標準写 真と比較することによって测定籄所の応力を判定する ことができる.

\section{3 適用温度範囲}

めっき層に成長粘子が発生し始める応力振幅の限界 值 $\sigma_{p}$ と応力綝返乙数 $N$ との関係を表す曲線, $\sigma_{p}-N$ 曲線は Fig. 4 亿示すと扔りである。

罒から明らかなよらに, 試駼温度が室温から $100^{\circ} \mathrm{C}$ の間では同じ $N$ に詨する $\sigma_{b}$ の值はほとんど変化しな 


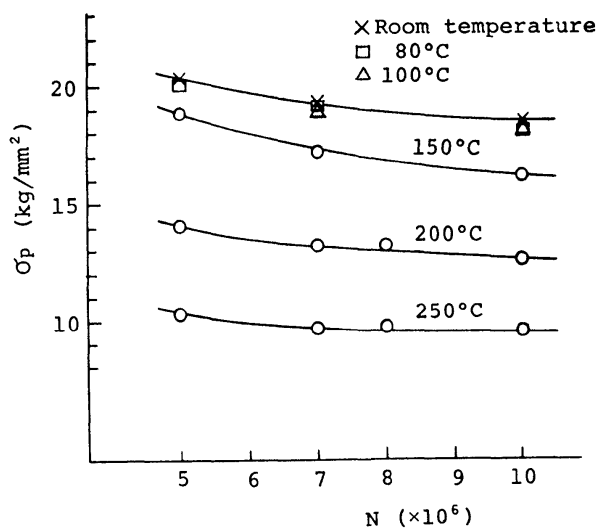

Fig. 4. $\sigma_{p}-N$ curves for different temperatures.

い.したがって，これらの温度範囲では温度補償の必 要はないといってよい。しかし，100 $\mathrm{C}$ を越えると， $\sigma_{p}$ の値は低くなり，特に $150^{\circ} \mathrm{C}$ 以上になると， $\sigma_{p}$ の 低下汇著しくなる。

$300^{\circ} \mathrm{C}$ 程度まではめっき層には再結晶は起らない。 しかし, 試験温度が高くなるにしたがって発生する成 長粒子は小さくなる，試験温度 $250^{\circ} \mathrm{C}$ 位までは成長粒 子を観察することが可能であるが， 300 Cでは成長粒 子が著しく微細になり, 観測が不明確になる. したが って, 本方法の適用温度の上限は $250^{\circ} \mathrm{C}$ 位といえよう。 銅めっき法の適用できる温度の下限はー50年である ことがすでに明らかにされているので，本方法と合せ て用いれば銅めっき法の適用温度範囲は $-50^{\circ}$ Cから $250{ }^{\circ} \mathrm{C}$ までであるといえる。

Fig. 5 にゼラチン添加量と $\sigma_{p}$ の関係を示した.こ れは室温に括いて応力繰返し数 $N=3 \times 10^{6}, 4 \times 10^{6}$, $5 \times 10^{6}$ の各場合について実験したものであるが，ゼラ チンを微量添加することによって $\sigma_{p}$ の值は著しく大

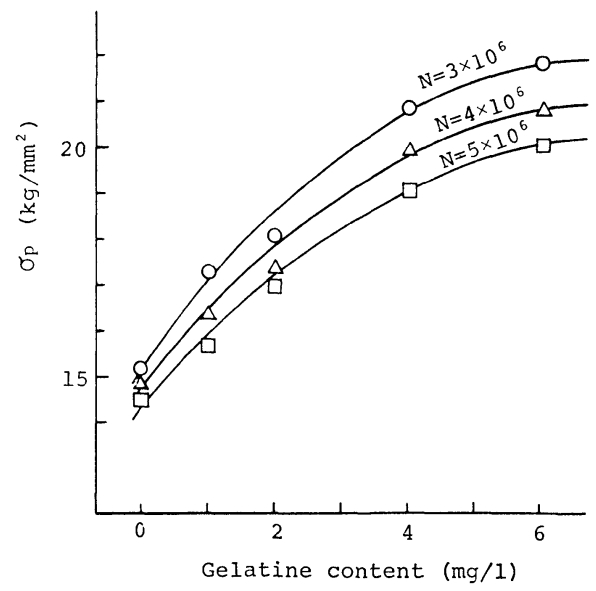

Fig. 5. Relation between proper stress and gelatine content.
きくなることがわかる。

ゼラチン無添加の場合には，高い応力を測定しょう

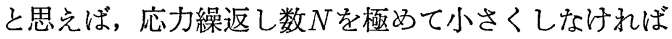
ならない，しかし，応力繰返し数が小さいところでは $\sigma_{p}-N$ 曲線の傾斜が大きいから， $N$ のわずかな誤差に よって $\sigma_{p}$ の值は大きく変り, 大きな測定誤差を生じ やすい，したがって，応力繰返し数を少くするのにも 限度がある。しかしながら，上述のように，めっき液 にゼラチンを添加すれば比較的大きな $\sigma_{p}$ に対しても 繰返し数は $N=3 \sim 5 \times 10^{6}$ といら大きな值になるので, 大きな応力を精密に測定する場合などに利用すれば効 果的である.

\section{4 結言}

従来より， $80^{\circ} \mathrm{C}$ 以上の高温で銅めっき法を適用する ことは困難であるとされてきた. しかし, 本研究の結 果から, 酸めっき液に微量のゼラチンを添加すれば, $250^{\circ} \mathrm{C}$ 程度の高温においても，銅めっきを用いて応力 測定を行うことが可能であることが明らかになった。

この方法をニッケルめっきを用いた場合と比較する と, 銅めっきの方がニッケルめっきよりも取り扱いが はるかに容易である。また，ニッケルめっきの適用温 度範囲は, 使用しためっき液によってかなりばらつき があるようであるが，ほぼ100～ 200 程度であり，ゼ ラチン添加の銅めっきの方がかなり適用温度範囲が広 いようである. しかし，ニッケルめっきでは高温にお いてめっき表面に発生するはん点を観測できるのに対 して，銅めっきでは表面が酸化してしまい，はん点を 観察するのが不可能になることがその欠点である．以 上の結果から，両者は先れぞれ長所，短所をるってい るから，測定の目的に応じてこれらの方法を使いわけ ることが必要であるとい方よう。

終りに，有益なご助言を賜った中部工業大学の大久 保㲠教授に対し深く感謝の意を表したい。

\section{参 考 文 献}

1）大久保肇，細野喜久雄，柴田昌広，日本機械学会論文集， 33-248, 548 (1967).

2）清家政一郎, 細野喜久雄, 大原久宜, 加藤 章, 日本機 械学会論文集, 41-352，3410（1975）.

3）清家政一郎, 細野喜久雄, 加藤 章, 日本機械学会論文 集, 41-352, 3416 (1975).

4）清家政一郎, 細野喜久雄, 太田仁史, 日本機械学会講演 論文集, No. 760-12, 254 (1976).

5) Okubo, H., and Kato, A., J. Strain Analysis, Inst. Mech. Engrs., 12-1, 41 (1977).

6）清家政一郎，細野喜久雄，宇野荘司，日本機械学会論文 集, 39-325, 2677 (1973). 